\title{
Structural Polypeptides of the Enteropathogenic Bovine Coronavirus Strain LV-138
}

\author{
By \\ I. HAJER ${ }^{1}$ and J. STORZ \\ Department of Microbiology, \\ College of Veterinary Medicine and Biomedical Sciences, Colorado State University, \\ Fort Collins, Colorado, U.S.A.
}

With 5 Figures

Accepted August 17, 1978

\section{Summary}

The bovine coronavirus strain LY-138 was purified by differential as well as velocity and isopycnic centrifugation in sucrose or CsCl gradients. The substrate for purification was contents of the small intestine of experimentally inoculated calves. This strain is highly enteropathogenic, but it could not yet be propagated in cultured cells. Intact virions had a density of $1.245 \mathrm{~g} / \mathrm{cm}^{3}$ in CsCl and $1.185 \mathrm{~g} / \mathrm{cm}^{3}$ in sucrose. A spherical core-like structure with an average diameter of $82 \mathrm{~nm}$ remaining after treatment with chloroform had a density of $1.299 \mathrm{~g} / \mathrm{cm}^{3}$ in $\mathrm{CsCl}$ and $1.201 \mathrm{~g} / \mathrm{cm}^{3}$ in sucrose.

Seven distinct bands of polypeptides and 4 shoulders were detected after electrophoresis of SDS-solubilized virions in polyacrylamide gels. The approximate molecular weights ranged from 110,000 to 36,000 . Four of the bands gave a PAS positive reaction. These 4 glycoproteins and an additional protein with an approximate molecular weight of 70,000 were removed by chloroform treatment. The remaining core-like structure contained the 2 polypeptides VP 3 and VP 7.

\section{Introduction}

Among the coronaviruses there are strains that cause intestinal infections leading to enteritis and diarrhea in swine $(10,32)$, rodents $(28)$, dogs (2), calves (26) and possibly man (6). Factors determining the unique enteropathogenic properties of these coronaviral strains have not been defined (33). Some of the enteropathogenic coronavirus strains have been propagated in cultured cells $(2,25,28,30)$ but many others could not be adapted to cell cultures $(6,9,28)$. An example of such a strain is the highly enteropathogenic strain LY-138 infecting

1 Dr. I. HA.Jer is now in the Department of Virology, Veterinary Research Administration, El Amarat, Khartoum, Sudan. 
calves. Several attempts to adapt this strain to different types of cultured bovine fetal cells were unsuccessful $(8,9,14)$. This viral agent was maintained by oral inoculation and intestinal infection of newborn calves (8). Electron microscopic evaluation of negatively stained preparations of purified virus particles revealed coronaviral morphology (9), and these viral preparations contained 3 antigens reacting with bovine coronavirus antiserum (14). Ultrastructural cytologic intestinal changes caused by this virus were investigated (8). Viral strain LY-138 was employed in studies on intracellular and body fluid alterations and on changes in intracellular and extracellular ion concentrations that occurred in the course of diarrhea following oral inoculation of calves $(19,27)$.

Further characterization of this highly virulent enteropathogen was essential. This report contains results of studies on the structure, physical properties, and polypeptide composition of the bovine coronavirus strain LY-138 purified from intestinal infections of experimentally inoculated calves.

\section{Materials and Methods}

\section{Virus Purification and Buoyant Density Determination}

Contents of the small intestine of experimentally infected calves 3 days after oral inoculation served as substrates for virus purification. As an initial step, the virus was partially purified by sucrose velocity centrifugation as described earlier (9). The partially purified virus suspension or such suspensions treated to split the virions were layered onto $1.1-1.5 \mathrm{~g} / \mathrm{cm}^{3}$ preformed linear $\mathrm{CsCl}$ gradients or $20-50$ per cent performed linear sucrose gradients in TEN buffer $(0.01 \mathrm{M}$ tris-hydrochloride, $0.001 \mathrm{M}$ EDTA, $0.1 \mathrm{~m} \mathrm{NaCl}$ ). After banding by isopyenie centrifugation at $81,000 \times g$ for 24 hours in the SW 40 rotor driven in a Beckman Model L 2-65 B ultracentrifuge, one $\mathrm{ml}$ fractions were collected. The refractive indices of band fractions were determined in a Fisher refractometer, and the buoyant densities were calculated from a calibration of density versus refractive index chart. Each fraction was dialysed overnight in 1 per cent ammonium acetate at $4^{\circ} \mathrm{C}$ and concentrated to the original volume by extracting water with 40 per cent polyethylene glyeol $(w / v)$ in 1 per cent ammonium acetate. Purity of the fractions was monitored by electron microscopic examination following negative staining with 1.5 per cent phosphotungstic (PTA) acid.

\section{Isolation of Viral Cores}

Purified virus suspensions were treated with 1 in 10 parts chloroform, or diethylether, 0.5 per eent Tween-80 or 0.5 per cent Nonidet P. 40 (NP.40). The mixtures were shaken at room temperature for 30 minutes. After low speed centrifugation at $3000 \times g$ for 15 minutes, $1.5 \mathrm{ml}$ of the aqueous phases were layered onto a linear $20-40$ per cent sucrose gradient in TEN buffer and centrifuged at $81,000 \times g$ for 2 hours. The bands were localized by light scatter under a vertical beam of light and collected from the bottom of the tube. The band contents were dialysed overnight against 1 per cent ammonium acetate at $4^{\circ} \mathrm{C}$. The dialysate was concentrated to $1 / 5$ of the original volume as described above. Samples of each band were negatively stained with 1.5 per cent PTA for EM examination.

\section{Electron Microscopic Evaluation of Gradient Fractions}

The degree of purity and viral morphologic features of different density gradient fractions were monitored by EM examination. Dialyzed aliquots of different fractions were each placed on 300 mesh, formvar coated, carbon-stabilized grids which had been degreased by dipping into carbon tetrachloride. Excess fluid was withdrawn by blotting with a filter paper. The grids were air-dried and a drop of 1.5 per cent PTA at $\mathrm{pH} 6.5$ was added to the grids. Excess stain was withdrawn with filter paper. The grids were dried overnight in a vacuum oven operated at room temperature and a 
pressure differential of $1075 \mathrm{~g} / \mathrm{cm}^{3}$ (15 pounds/square inch). The specimens were examined with an Hitachi HU-12 electron microscope operated at 75,000 volts and a screen magnification of 40,000 . For size measurement of viral particles magnifications were calibrated against carbon-grating replica having 2160 lines per millimeter.

\section{Henagglutination Test ( $H A$ )}

Serial two-fold dilutions were made in PBS at a $\mathrm{pH}$ of 7.2 from each fraction obtained from $\mathrm{CsCl}$ isopycnic centrifugation in microtiter plates using microdiluters. Wach well then received an equal volume of $0.025 \mathrm{ml}$ of 0.5 per cent washed mouse exythrocytes. The results were read after incubation at room temperature for one hour and again after overnight incubation at $4^{\circ} \mathrm{C}$. The $\mathrm{HA}$ titer was expressed as the reciprocal of the highest dilution causing complete hemagglutination.

\section{Polypeptide Analysis by Polyacrylamide Gel Electrophoresis}

Polyacrylamide gels were prepared by a method similar to that of CALIGUrRI and coworkers (5) from solutions containing 7.5 or 10 per cent acrylamide, 0.27 per cent $\mathrm{N}, \mathrm{N}^{\prime}$-methylene bisacrylamide, 0.1 per cent SDS and $0.5 \mathrm{~m}$ urea. Polymerization was carried out by the addition of freshly prepared 0.1 per cent $N, N, N^{\prime}, N$-tetramethylene diamine (TEMED) and 0.15 per cent ammonium persulfate in $6 \mathrm{~mm}$ diameter, $12 \mathrm{~cm}$ long glass tubes. The gels were $10 \mathrm{~cm}$ long. The gels were electrophoresed for 2 hours at $3 \mathrm{~mA} / \mathrm{gel}$ before samples were applied.

Purified virus and cores were concentrated to approximately $2 \mathrm{mg}$ protein $/ \mathrm{ml}$ as determined by the method of Lowry and coworkers (21). An amount of $0.3 \mathrm{ml}$ of each of these concentrated preparations was solubilized according to the method of Marzex and coworkers (24) by adding drops of sodium dodecyl-sulfate (SDS) to a final concentration of 1 per cent, 2 mercapto-ethanol to a final concentration of 1 per cent and urea to $2 \mathrm{~m}$ final concentration, followed by boiling for 3 minutes in a water bath. A drop of glycerine and a drop of 0.04 per cent bromophenol blue (BPB) were added after the preparation had cooled and the samples were applied to the gels. The electrophoresis buffer was 0.1 MI sodium phosphate $\mathrm{pH} 7.2$, containing 0.1 per cent SDS and $0.5 \mathrm{M}$ urea. Electrophoresis was carried out at room temperature for 15 hours at $3 \mathrm{~mA} / \mathrm{gel}$.

Gels were removed from the glass tubes by air pressure using a rubber bulb. The gels were fixed overnight in 20 per cent sulfosalicylic acid and stained for at least 12 hours with Coomassie brilliant blue. The gels were destained with several changes of 7 per cent acetic acid in 10 per cent methanol. Destained gels were scanned with a Gelman Scanner, and the migration distance of each polypeptide was measured. The molecular weights of the polypeptides were determined from a standard curve drawn from migration distances of marker proteins of known molecular weight. The marker proteins were cytochrome C, 11,700 (Sigma Chemical Company, Saint Louis, Missouri), pepsin, 35,000 (Sigma), ovalbumen, 43,000 (Sigma), lipase, 38,000 (Sigma), and bovine serum albumen (BSA) 68,000 (Sigma).

\section{Glycoprotein and Lipoprotein Staining}

For glycoprotein staining, a modification of the periodic Schiff (PAS) as employed by ZACHARIUS and coworkers (34) was used. Gels were fixed in 12.5 per cent trichloroacetic acid (TCA) for 30 minutes, rinsed in distilled water and oxidized in 1 per cent periodic acid in 3 per cent acetic acid for 1 hour. After eight 10-minute washings in distilled water, the gels were stained for 50 minutes in acidified 0.5 per cent basie fuchsin-sulfite (Schiff Reagent). The stain was prepared by dissolving basic fuchsin in fresh 0.5 per cent potassium metasulfide and $0.1 \mathrm{M}$ HCL. After three 10-minute washings with freshly prepared 0.5 per cent potassium metasulfide, the gels were destained in distilled water and stored in 7 per cent acetic acid. Lipoproteins were stained by placing the gels in 0.7 per cent Sudan Black B in polypropylene glyeol for 2 hours followed by destaining with several changes of 85 per cent polypropylene glycol for 3 days (22). After destaining, the gels were rehydrated in distilled water for 3 days. Specimens for detection of proteins, lipoprotein, and glycoproteins were prepared and electrophoresced at the same time. 


\section{Results}

\section{Buoyant Density of Purified Virus and Structural Components}

Velocity centrifugation in a sucrose gradient displayed two closely placed bands 5.8 and $6.3 \mathrm{~cm}$ from the meniscus of the gradient. Electron microscopic examination of negatively stained samples from the two bands revealed that the top band consisted of membranous fragments of viral particles and residual cellular components. The lower band contained enveloped viral particles with petal-shaped envelope projections.

When the virus band obtained at the $6.3 \mathrm{~cm}$ distance in sucrose velocity centrifugation was isopycnically banded in $20-50$ per cent linear sucrose gradients and 1.1-1.5 g/ $/ \mathrm{cm}^{3} \mathrm{CsCl}$ gradients, single sharp bands were obtained. The bands had a density of $1.245 \mathrm{in} \mathrm{CsCl}$ and 1.185 in sucrose. The maximum titers of hemagglutinating activity coineided with these bands as shown in Figure 1.

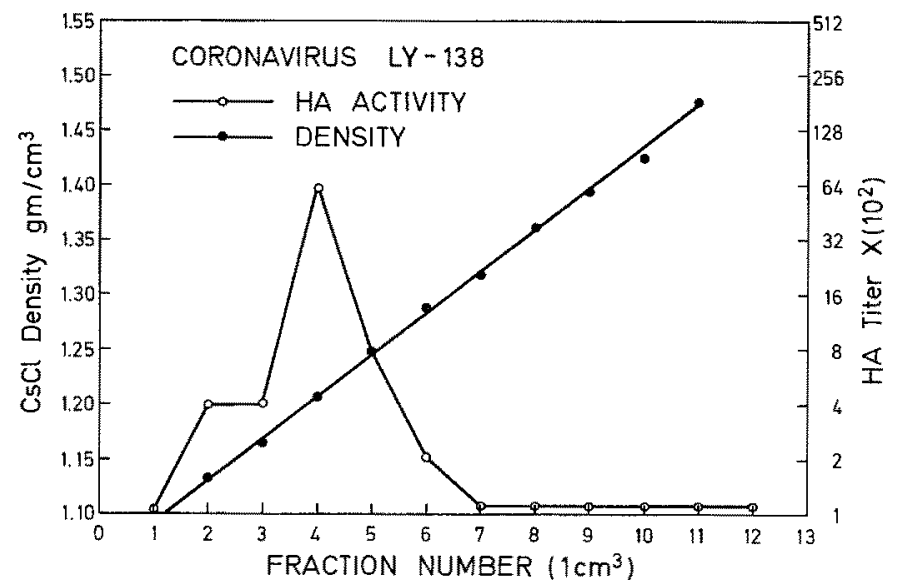

Fig. 1. Isopyenic centrifugation of bovine coronavirus LY-138 in CsCl. The virus band corresponded to a density of $1.245 \mathrm{~g} / \mathrm{cm}^{3}$ and coincided with the maximum hem. agglutination activity

Electron microscopic examination of negatively stained samples from either $\mathrm{CsCl}$ or sucrose isopycnic bands revealed clean fields of numerous roughly spherical particles. Elongated and other pleomorphic forms of virions were also seen. Some particles seemed to have been penetrated by the stain. Viral particles were enveloped and varied in size from $70-120 \mathrm{~nm}$ and possessed 15 to $20 \mathrm{~nm}$ petal-shaped surface projections. These projections were widely spaced and gave the typical appearance of the solar corona (Fig. 2).

Treatment of purified virus with chloroform for 30 minutes followed by isopyenic centrifugation in $\mathrm{CsCl}$ or sucrose resulted in visible bands at densities of $1.299 \mathrm{~g} / \mathrm{cm}^{3}$ and $1.201 \mathrm{~g} / \mathrm{cm}^{3}$, respectively. These bands contained particles without projections and envelopes, and consequently they were considered to represent viral core-like material. These relatively homogeneous core-like struetures were round. Measurements were made on 100 particles and gave a mean 
diameter of $82 \mathrm{~nm}$. The core-like structures tended to stick to each other on the grids and formed aggregates. Although subunits appeared on the surface of the cores, no discernible symmetry in arrangement could be detected (Fig. 3). The particles in this fraction were entire, and material protruding from them was not seen. Treatment with diethyl ether, Tween-80 and NP.40 caused disassembly of the virus so that no isopycnic bands were detected for morphological and biophysical analysis.

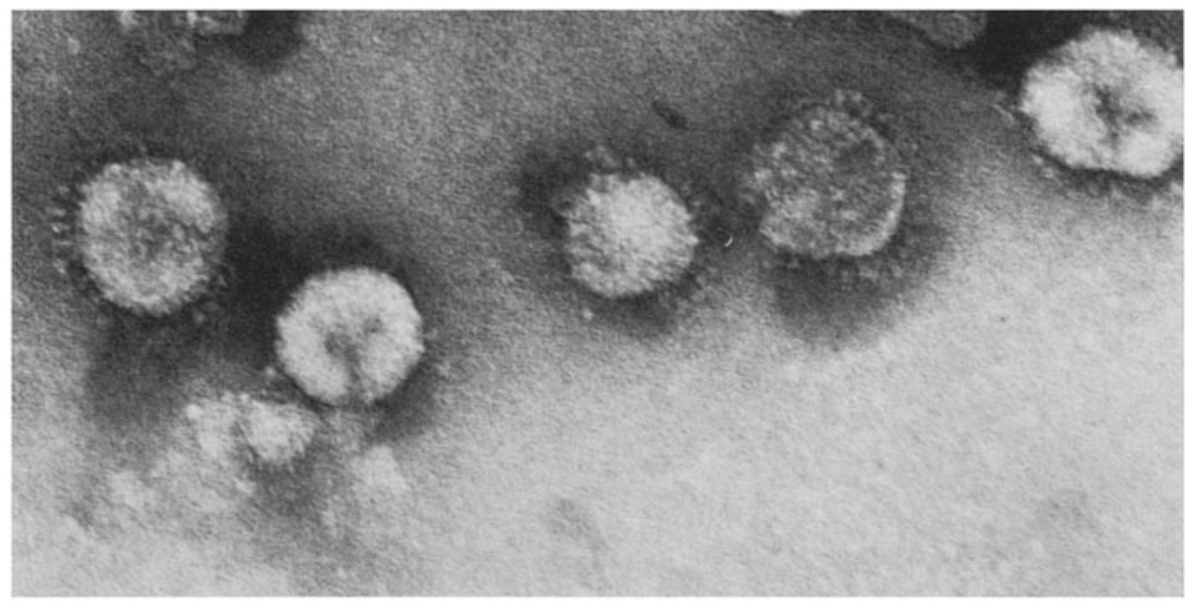

Fig. 2. Electron photomicrograph of sucrose gradient purified particles of bovine coronavirus strain LY-138. The particles are moderately pleomorphic and have petallike projections typical of coronavirus morphology. Stained with 1.5 per cent PTA. Magnification: $\times 155,000$

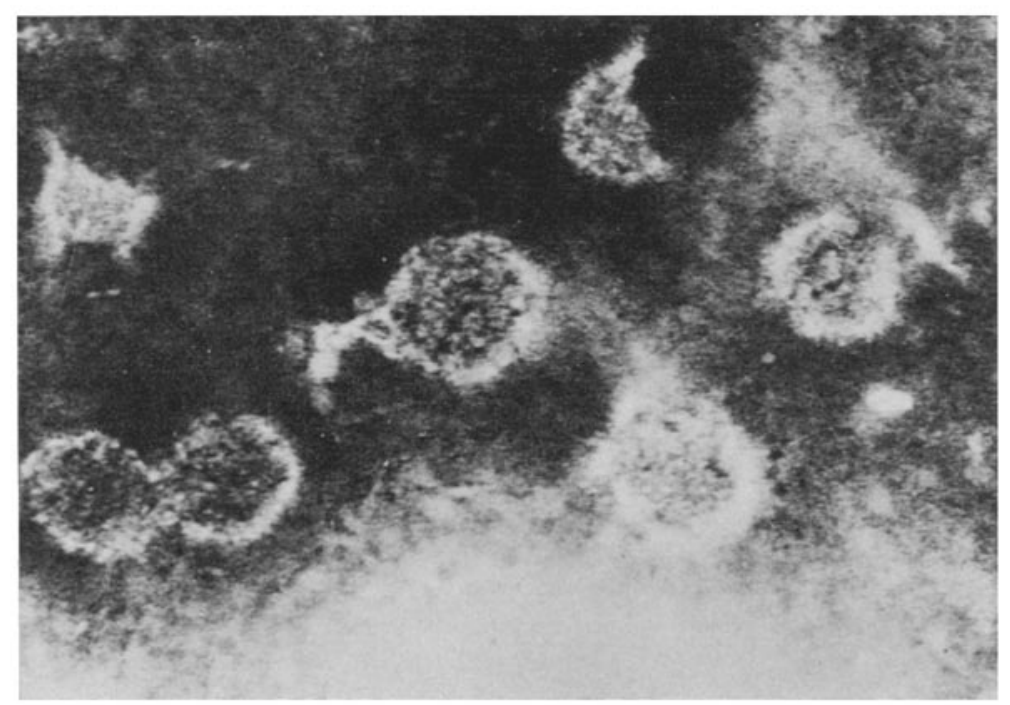

Fig. 3. Coronavirus LY-138 core-like structures. Virions were treated with 1 in 10 parts chloroform, purified by sucrose isopyenic centrifugation and negatively stained with 1.5 per cent PTA. Magnification: $\times 204,000$ 


\section{Polypeptide Composition of Virions and Core-Like Structures}

Purified virions and core-like structures were solubilized by SDS, 2-mercaptoethanol and urea. The polypeptides were separated by polyacrylamide gel electrophoresis. The molecular weight estimates were determined in 10 per cent acrylamide gels in which plots of relative mobilities of standard proteins were linear with respect to the log of their molecular weights. Ten percent acrylamide gels gave better resolution in polypeptide separation than 7.5 per cent. gels. In both cases, however, it was found necessary to apply about $2 \mathrm{mg}$ of protein to gels before stained polypeptide bands were detectable.

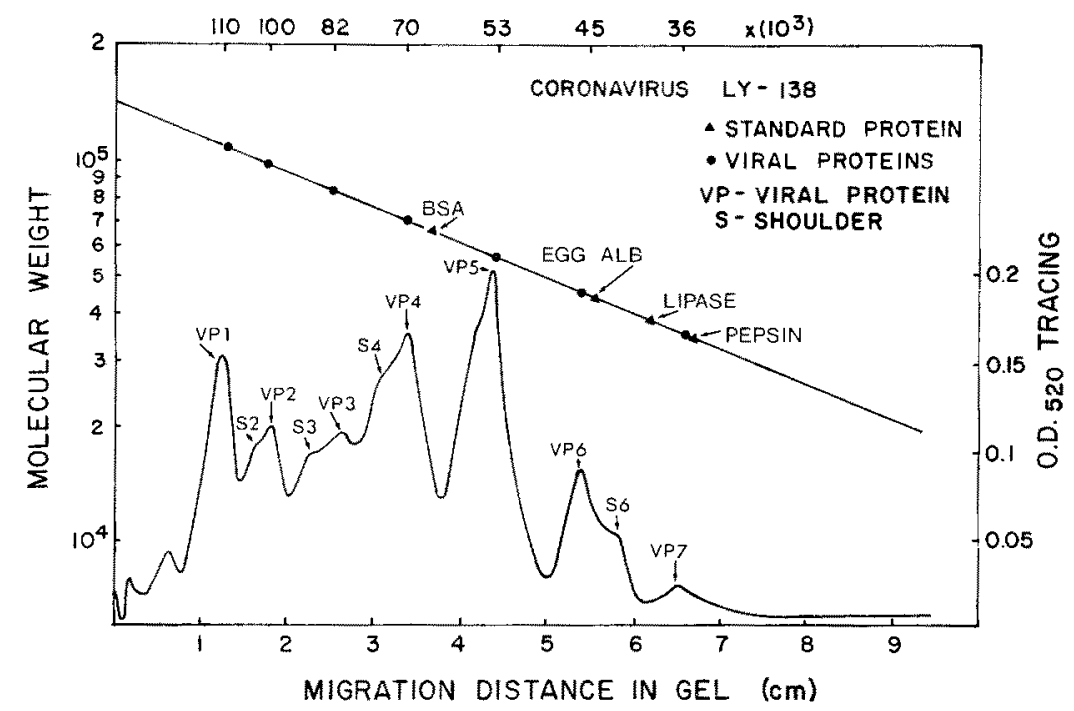

Fig. 4. Densitometric tracing at $520 \mathrm{~nm}$ of protein components of coronavirus LY-138 and their molecular weights as determined in 10 per cent polyacrylamide gels

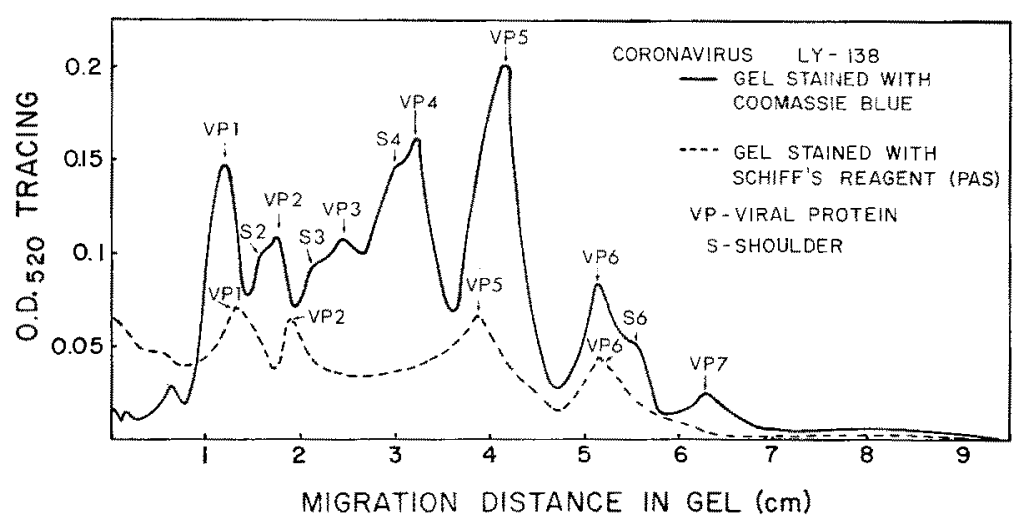

Fig. 5. Densitometric tracing at $520 \mathrm{~mm}$ of chemical staining reactions of polypeptides of coronavirus LY-138 separated by PAGE 
At least 7 distinct bands were visible after electrophoresis and Coomassie brilliant blue staining of gels containing solubilized polypeptides of intact virus (Fig. 4). There were often 1 or 2 minor inconspicuous bands near the top of the gel. The viral polypeptides were designated VP1, VP2, VP3, etc. in order of increasing electrophoretic mobility of the bands. All these 7 bands were repeatedly obtained. Four shoulders (S) were observed. Three trailed VP2, VP3, and VP4, and one was in front of VP6. The approximate molecular weights of the LY-138 structural polypeptides calculated from 10 per cent acrylamide gel are summarized in Table 1 . When the gels were PAS stained to reveal the carbohydrate containing proteins, 4 distinct reddish-pink bands were detected in gels containing polypeptides of solubilized intact virus. These bands coincided with VP1, VP2, VP5, and VP6 (Fig. 5). Out of the 5 proteins split from the virion by chloroform treatment only VP4 was not found to be glycosylated. Sudan black staining of the gels did not reveal the presence of lipoproteins.

PAGE-analysis of the core-like structures in the isopyenic band after chloroform treatment revealed that only the viral proteins VP 3 and VP7 were present. Consequently, the viral structures removed by chloroform-treatment contained VP1, VP2, VP4, VP5, and VP6.

Table 1. Structural polypeptide of bovine coronavirus $L Y-138$

\begin{tabular}{|c|c|c|c|c|c|}
\hline Protein & $\begin{array}{l}\text { Approximate } \\
\text { molecular } \\
\text { weight } \\
\left(\times 10^{3}\right)\end{array}$ & $\begin{array}{l}\text { Percent } \\
\text { of total } \\
\text { protein }\end{array}$ & $\begin{array}{l}\text { PAS } \\
\text { reaction }\end{array}$ & $\begin{array}{l}\text { Proteins } \\
\text { after } \\
\text { chloroform }\end{array}$ & $\begin{array}{l}\text { Nature of } \\
\text { protein }\end{array}$ \\
\hline $\begin{array}{l}\mathrm{VP} 1 \\
\mathrm{~S} 2\end{array}$ & 110 & 20 & + & - & Glycoprotein \\
\hline $\begin{array}{l}\text { VP } 2 \\
\text { S3 }\end{array}$ & 100 & 8 & + & - & Glycoprotein \\
\hline $\begin{array}{l}\text { VP } 3 \\
\$ 4\end{array}$ & 82 & 8 & - & + & Protein \\
\hline VP 4 & 70 & 22 & - & - & Protein \\
\hline VP 5 & 53 & 23 & + & - & Glycoprotein \\
\hline $\begin{array}{l}\text { VP } 6 \\
\text { S } 6\end{array}$ & 45 & 10 & + & - & Glycoprotein \\
\hline VP 7 & 36 & 6 & $-\ldots$ & + & Protein \\
\hline
\end{tabular}

$\mathrm{VP}=$ viral protein

$\mathrm{S}=$ shoulder

Molecular weight estimates were made for viral proteins; shoulders were not included

\section{Discussion}

Viral strain LY-138 could not yet be adapted to cultured cells $(9,14)$. Since this strain is highly enteropathogenic (8) and had been used in physiopathologic and ultrastructural investigations of virus-induced enteritis and diarrhea $(18,27)$, means for further identification and characterization were sought.

Studies on the morphology, antigenic structure, HA activity, morphogenesis and effect on infected intestinal epithelial cells identified some coronaviral characteristics of strain LY-138 $(8,9,14)$. The enteropathogenic properties would group this strain with others such as the virus of transmissible gastro-enteritis (TGE) 
of swine which differ in their resistance to a $\mathrm{pH}$ of 3 from coronaviruses associated with respiratory and other infections $(25,30)$.

Intestinal contents of experimentally infected calves were used as substrates for viral morphologic, structural and biophysical analysis. The method used for virus purification and concentration from in vivo samples resulted in preparations containing large amounts of highly purified virus particles. The degree of virus purity was monitored by density determination, electron microscopic analysis, immunodiffusion, and hemagglutination. The morphological integrity and the hemagglutinating ability of the virus were preserved by the method of purification employed. The virions banded isopyenically at a density of $1.245 \mathrm{~g} / \mathrm{cm}^{3}$ in $\mathrm{CsCl}$ and $1.185 \mathrm{~g} / \mathrm{cm}^{3}$ in sucrose. This result is in close agreement with the densitites given for coronaviridae in the report of the study group on coronavirus (33).

Several past attempts to visualize the internal structure of coronaviruses by EM examination of viruses treated with different surface active and lipid solvents were reported $(1,11,18,23)$. All the procedures used resulted in disintegration of virus, and the internal components of coronavirus have not been clearly characterized. Treatment of LY-138 virions with 1 in 10 parts chloroform followed by isopyenic centrifugation removed from the virions envelope components to produce core-like, round structures which contained 2 polypeptides. The average diameter in negatively stained preparations was $82 \mathrm{~nm}$, and the buoyant density of LY-138 core-like structure was $1.299 \mathrm{~g} / \mathrm{cm}^{3}$ in CsCl and $1.201 \mathrm{~g} / \mathrm{cm}^{3}$ in sucrose. Following treatment of the TGE virus with 1 per cent NP40, GARWES and coworkers (11) found $60-70 \mathrm{~nm}$ structures with a $\mathrm{CsCl}$ density of $1.295 \mathrm{~g} / \mathrm{cm}^{3}$. Further analysis of the core-like structures is needed to determine whether they represent viral cores or virions merely stripped of envelope projections.

The packing arrangement of the nucleocapsid, whether helical or compound, could not be unequivocally determined from our electron microscopic analysis. However, viral core-like structures maintained a round configuration similar to the condensing cores reaching a diameter of $60 \mathrm{~nm}$ that were detected in the course of studies on the morphogenesis of virions in $\mathrm{LY}$-138-infected intestinal cells (9). Obvious thread-like structures as described for infectious bronchitis virus by others were not detected (18). Evidence for helical symmetry was thus not found. Several coronaviruses appear to have ribonucleoprotein cores that are formed before envelopment and that can exist without the envelope, a characteristic that was previously observed in oncornaviruses $(3,4,7)$. The possibility of a similar cubic or binal symmetry for coronaviruses should be considered.

At least 7 polypeptides were reproducibly demonstrated from purified virions of strain LY-138 under our conditions of dissociation of purified virus by SDS, urea and mercaptoethanol and electrophoretic display in polyacrylamide gels. Occasionally, 1 or 2 very minor bands appeared near the top of the gels. There were also shoulders associated with VP2, VP3, VP4, and VP 6, that could represent viral or cellular polypeptides. Four of these proteins were PAS positive for carbohydrates. In addition, polypeptide analysis of LY-138 core-like structures revealed that they contained the two viral structural proteins VP3 and VP7. Garwes and Pocock (12) detected 4 major and 2 minor proteins of which 3 contained carbohydrates in an analysis of a TGE strain. Our results of the presence of at least 7 proteins in the virions correspond to those obtained with the human 
coronavirus $\mathrm{OC} 43(16)$ and with the virus of avian infectious bronchitis (23). In both instances 7 polypeptides were described and 4 of these were glycosylated. Recently, HIERHolzer (15) observed that another human coronavirus strain, $229 \mathrm{E}$, had 6 glycoproteins. In contrast, STuRMan (31) displayed 4 size classes of structural proteins in preparations of the murine coronaviral strain A59 labeled with radioactive amino acids. Three of these were glycosylated. Two of these size classes consisted of a glycoprotein with a molecular weight of 180,000 which was converted to a glycoprotein of 90,000 . Polypeptides with molecular weights close to 200,000 were not detected in our gels displaying the proteins of a virus purified from intestinal contents and analyzed spectrophotometrically.

Dissociation of the intact virions and core-like structures by SDS, urea, and mercaptoethanol followed by PAGE enabled us to locate and identify structural proteins in two viral components. This technique placed all viral glycoproteins into the components removed by chloroform treatment which represent viral envelopes. These results were in complete agreement with previous findings on coronavirus strain $\mathrm{OC} 43$ which also contained 4 glycoproteins of which two were associated with the envelope projections (16). It is of interest to observe that out of the 5 proteins removed by chloroform treatment only VP4 was not a glycoprotein. In comparison, bromelain treatment removed the 3 glycoproteins VP1, VP2, and VP5 from the virions of infectious bronchitis (23). All of the 180,000 and 90,000 glycoprotems of the murine coronavirus strain A59 were removed by protease treatment, and 20 per cent of a third glycoprotein with 23,000 molecular weight was digested leaving a protease resistant protein of 18,000 (31).

Recently, infectious RNA of the avain infectious bronchitis virus was prepared in two different laboratories $(20,29)$. The molecular weight was found to be 5.5 to $5.7 \times 10^{6}$ in one report (29) and $8.1 \times 10^{6}$ in the other $(20)$. If a similar genetic system functions in enteropathogenic coronaviruses, this genetic information would be sufficient to code for more than the 7 polypeptides which were detected in the coronavirus starin LY-138. However, another report presented evidence for a $60-70 \mathrm{~S}$ RNA of the TGE virus. This RNA of a molecular weight of $9 \times 10^{6}$ dissociated into $35 \mathrm{~S}$ and $4 \mathrm{~S}$ subunits (13).

It is evident that the coronavirus family may comprise presently viruses of diverse properties. Detailed work is justified to resolve these apparent differences.

\section{Acknowledgments}

Part of a thesis submitted by the senior author in partial fulfillment of the requirements for the Ph. D. Degree at Colorado State University. These investigations were supported by the Colorado Agricultural Experiment Station through Regional Project W-112, by NIH Research Grant AI-08420, by funds from Jensen-Salsbery Laboratories, Kansas City, MO, and through a generous gift donated anonymously to the Dr. Tracy Rhodes Scholarship Fund. Published as Journal Paper No. 2382, Colorado Agricultural Experiment Station.

\section{References}

1. Berriy, D. M., Crutorshank, J. G., ChU, H. P., Wells, R. J. H.: The structure of infectious bronchitis virus. Virology 23, 403-407 (1964).

2. Binn, L. N., Lazar, E. C., Keenan, K. P., Huxsoli, D. L., Marchwickt, R. H., STRAno, A. J.: Recovery and characterization of a coronavirus from military dogs with diarrhea. In: Animal Health (Proc. of the 78th Annual Meeting, U.S. Anim. Health Assoc., Roanoke, Virginia, 1974), 359-366 (1975). 
3. Bolognesi, D. P., Montelaro, R. C., Frank, H., Schäfer, W.: Assembly of type C Oneornaviruses: A model. Science 199, 183-186 (1978).

4. Bolognesi, D. P., Gelderblom, H., Bauer, H., Mölurng, K., Huper, G.: Polypeptides of avian RNA tumor viruses. V. Analysis of the virus cores. Virology 47, $567-576(1972)$.

5. Cartgutri, L. A., KlenK, H. D., Choprin, P. W. : The proteins of the parainfluenze virus SV 5. I. Separation of virion polypeptides by polyacrylamide gel electrophoresis. Virology 39, 460-466 (1969).

6. Caul, E. O., Paver, W. K., Clarke, S. K. R. : Coronavirus particles in faeces from patients with gastroenteritis. Lancet $\mathbf{i}, 1192-1193$ (1975).

7. Coffin, J. M., Temin, H. M.: Comparison of Rous sarcoma virus specific deoxyribonucleic acid polymerases in virions of Rous sarcoma virus and in Rous sarcoma virus infected chicken cells. J. Virol. 7, 625-634 (1971).

8. DovGHRI, A. M., Storz, J.: Light and ultrastructural pathologic changes in intestinal coronavirus infection of newborn calves. Zentralbl. Vet. Med. (B) 24, $367-385(1977)$.

9. Doughri, A. M., Storz, J., HAJer, I., Fernando, H. S.: Morphology and morphogenesis of a coronavirus infecting intestinal epithelial cells of newborn calves. Expt. mol. Pathol. 25, 355-370 (1976).

10. Doyle, L. P., Hutchings, L. M.: A transmissible gastro-enteritis in pigs. J. Amer. vet. Med. Ass. 108, 257-259 (1946).

11. Garwes, D. J., Pocock, D. H., PikE, B. W.: Isolation of subviral components from transmissible gastro-enteritis virus. J. gen. Virol. 32, 283-294 (1976).

12. Garwes, D. J., Pocock, D. H.: The polypeptide structure of transmissible gastroenteritis virus. $J$. gen. Virol. 29, 25-34 (1975).

13. Garwes, D. J., Pocock, D. H., WiJaszka, T. M. : Identification of heat-dissociable RNA complexes in two porcine coronaviruses. Nature (London) 257, 508-510 (1975).

14. HAJER, I., Storz, J.: Antigens of bovine coronavirus strain LY-138 and their diagnostic properties. Amer. J. vet. Res. 39, $441-444$ (1978).

15. Huenholzer, J. C.: Purification and biophysical properties of human coronavirus 229 E. Virology 75, 155-165 (1976).

16. Hierholzer, J. C., Palmer, E. L., Whitfield, S. G., Kaye, H. S., Dowdee, W. R. : Protein composition of coronavirus OC43. Virology 48, 516-527 (1972).

17. Kaye, H. S., Hterholzer, J. C., Dowdle, W. R. : Purification and further characterization of an "IBV-like" virus (coronavirus). Exp. Biol. Med. 135, 457-463 (1970).

18. Kennedy, D. A., Johnson-Lussenburg, M.: Isolation and morphology of the internal component of human coronavirus strain $229 \mathrm{E}$. Intervirology 6, 197-206 (1976).

19. Lewis, L. D., Prruxrss, R. W.: Diarrheic induced ehanges in intracellular and extracellular ion concentrations in neonatal calves. Ann. Rech. Vétér. 4, 99-111 (1973).

20. Lomnrcat, B., Kennedy, I. Genome of infectious bronchitis virus. J. Virol. 24, $99-107(1977)$.

21. Lowry, O. H., Rosebrough, N. J., Farr, A. L., Randald, R. J.: Protein measurement with the follin phenol reagent. $J$. biol. Chem. 193, 265-275 (1951).

22. LunA, L. G.: Manual of Histopathologic staining methods of the Armed Forces Institute of Pathology, 3rd Ed. New York: McGraw-Hill Book Co. 1968.

23. Madnaughton, M. R., Madge, M. H., Davies, H. A., Dourmashkin, R. R.: Polypeptides of the surface projections and the ribonucleoprotein of avian infectious bronchitis virus. J. Virol. 24, 821-825 (1977).

24. MaIzeL, J. V., Summers, D. F., SChaRFF, M. D. : SDS-acrylamide gel eleetrophoresis and its application to the proteins of poliovirus and adenovirus-infected human cells. J. Cell Physiol. 76, 273-288 (1970).

25. Molntosh, K.: Coronaviruses: A comparative review. Curr. Top. Microbiol. Immun. 63, 84-129 (1974). 
26. Mebus, C. A., Stain, E. L., Rhodes, M. B., Twrenaus, M. J. : Pathology of neonatal calf diarrhea induced by a coronavirus-like agent. Vet. Pathol. 10, 45--64 (1973).

27. Phillips, R. W., Lewis, I. D.: Viral induced changes in intestinal transport and resultant body fluid alterations in neonatal calves. Ann. Rech. Vétér. 4, 87-98 (1973).

28. Rowe, W. P., Hartley, J. W., CApps, W. I.: Mouse hepatitis virus infection as a highly contagious, prevalent, enteric infection of mice. Proc. Soc. exp. Biol. Med. $112,161-165(1963)$.

29. Schochetinan, G., STEvens, R. H., Stmpson, R. W.: Presence of infectious polyadenylated RNA in the coronavirus avian bronchitis virus. Virology 77, 772--782 (1977).

30. Sharper, R. L., Mebus, C. A., Bass, E. P.: Characterization of a calf diarrheal coronavirus. Amer. J. vet. Res. 37, 1031-1041 (1976).

31. STURMAN, L. S.: Characterization of a coronavirus. 1. Structural proteins: Fffects of preparative conditions on the migration of protein in polyacrylamide gels. Virology 77, 637-649(1977).

32. TaJma, N.: Morphology of transmissible gastro-enteritis virus of pigs. A possible member of coronaviruses. Arch. ges. Virusforsch. 29, 105-108 (1970),

33. Tyrret, D. A. J., Almeida, J. D., Cunntngenalu, C. H., Dowole, W. R., Hofstad, M. S., MoIntosh, K., Tajmia, M., Zakstelskaya, L. Y., Easterday, B. C., Kapikian, A., Bingham, R. W.: Coronaviridae. Intervirology 5, $76-82$ (1975).

34. Zacharius, R. M., ZELL, T. E., Morrtson, J. H., Woodlock, J. J.: Glycoprotein staining following electrophoresis on acrylamide gels. Anal. Biochem. 30, $148-152$ (1969).

Authors' address: Dr. J. Srokz, Institut für Virologie, Justus Liebig-Universität Giessen, Frankfurter Strasse 107, D-6300 Giessen, Federal Republic of Germany. Presently on leave from: Department of Microbiology, Colorado State University. Fort Collins, CO 80523, U.S.A.

Received July 11, 1978 